\title{
ESPETÁCULO LGBTIQ SOFIA -35: AUTOBIOGRAFIA E QUESTÕES DE GÊNERO DENTRO E FORA DA CENA
}

\section{CLEILSON QUEIROZ LOPES}

Universidade Federal do Estado do Rio de Janeiro

RESUMO

Neste artigo de pesquisa autobiográfica, ocupo o lugar de artista-pesquisador. Como principal objetivo, desejo analisar a criação dramatúrgica do espetáculo LGBTIQ Sofia -35, monólogo em que eu, enquanto ator e dramaturgo homossexual, me descontruo e reconstruo durante a peça, na tentativa de peceber como realidade e ficção se relacionam na construção da personagem Sofia. A partir das discussões contemporâneas sobre gênero, abordo questões como migração, saúde pública, educação e direitos da comunidade LGBTIQ. Utilizo a metodologia de livre expressão, amparada pela pesquisa bibliográfica e narrativas pessoais que fazem parte deste percurso, onde descrevo, analiso e reflito. Como resultado, percebi que a narrativa autobiográfica e LGBTIQ do espetáculo Sofia -35 consegue ajudar a desmontar os discursos dominantes heteronormativos através da arte, tensionando também a ilusão da realidade que coube ao espaço teatral até a primeira metade do século XX. As questões LGBTIQ, retratadas a partir da estética teatral autobiográfica, possibilitam ao espectador a reelaboração de realidades possíveis e mais justas, a partir do teatro.

Palavras-chave: Teatro autobiográfico. Dramaturgia. Gênero.

\section{ABSTRACT SPECTACLE LGBTIQ SOFIA -35: AUTOBIOGRAPHY AND GENDER ISSUES ON AND OFF THE SCENE}

In this article of autobiographical research, I occupy the place of artist-researcher. As a main objective, I wish to analyze the dramaturgical creation of the LGBTIQ spectacle Sofia -35 , a monologue in which I, as an actor and homosexual playwright, deconstruct and reconstruct myself during the play, in an attempt to understand how reality and fiction relate to the construction of the character Sofia. From contemporary discussions on gender, I address issues such as migration, public health, education, and LGBTIQ community rights. I use the methodology of free expression, supported by the bibliographical research and personal narratives that are part of this path where I describe, analyze and reflect. As a result, I have noticed that 
the autobiographical and LGBTIQ narrative of the Sofia-35 show can help to dismantle heteronormative dominant discourses through art, also stressing the space of illusion of reality that belonged to theater until the first half of the twentieth century. The LGBTIQ issues portrayed from the autobiographical theatrical aesthetics allow the viewer to re-elaborate possible and fairer realities from the theater.

Keywords: Autobiographical theater. Dramaturgy. Genre.

\section{RESUMEN ESPECTÁCULO LGBTIQ SOFIA -35: AUTOBIOGRAFÍA Y CUESTIONES DE GÉNERO DENTRO Y FUERA DE LA ESCENA}

En este artículo de investigación autobiográfica, ocupo el lugar de artista-investigador. Como principal objetivo, deseo analizar la creación dramatúrgica del espectáculo LGBTIQ Sofia -35, monólogo en el que yo como actor y dramaturgo homosexual, me descontruyo y me reconstruyo durante la pieza, en el intento de peceberse como realidad y ficción se relacionan en la construcción del personaje Sofía. A partir de las discusiones contemporáneas sobre género, abordo cuestiones como migración, salud pública, educación y derechos de la comunidad LGBTIQ. Utilizo la metodología de libre expresión, amparada por la investigación bibliográfica y narrativas personales que forman parte de este recorrido donde describo, analisis y reflexión. Como resultado constatado, percibí que la narrativa autobiográfica y LGBTIQ del espectáculo Sofia -35 consigue ayudar a desmontar los discursos dominantes heteronormativos a través del arte, tensando también el espacio de ilusión de la realidad que le tocó al espacio teatral hasta la primera mitad del siglo XX. Las cuestiones LGBTIQ retratadas a partir de la estética teatral autobiográfica, posibilitan para el espectador la reelaboración de realidades posibles y más justas desde el teatro.

Palabras clave: Teatro autobiográfico. Dramaturgia. Género.

Sempre me incentivaram a calar, a não me expressar, a não escrever. No Ceará, terra de minha memória e origem, o bom estudante era aquele que permanecia em silêncio. Como se tudo não bastasse, cresci numa família de três irmãs mais velhas, sendo eu o quarto filho e caçula, aquele que iria povoar a casa dos meus pais com netos e estudar medicina. Porém, as minhas escolhas fugiram do que era idealiza- do pelos meus pais. O teatro encantou-me de tal forma na infância e adolescência, que toda aquela brincadeira virou pesquisa e profissão. Só depois fui começar a entender os significados daquela curiosidade, que me levava a conhecer lugares, pessoas, artistas, escritas.

Começo este artigo situando os leitores sobre uma pequena parte da minha biografia, onde a fala foi por muitas vezes abafada e a 
experiência não era ouvida. Todavia, estas experiências, que povoaram meu corpo e minha mente, mais tarde surgem em forma de palavra, de poesia, de imagem e de metáfora. É justamente este o ponto a que quero me remeter. Sofia -351 para mim é mais que um espetáculo, é uma possibilidade de ter voz e vez, de ser escutado, de narrar e de ouvir, é a possibilidade de agir, e mais ainda, de perceber uma narrativa que multiplica os seus significados quando se transforma em obra artística no teatro.

Sofia -35 é minha primeira dramaturgia, minha primeira autobiografia, uma narrativa onde dramaturgo e ator buscam acentuar suas complexidades de forma poética. É uma experiência, um mudar de calçada ao ver uma travesti na rua pela primeira vez, uma memória que me inquietou durante anos e que se potencializou como espetáculo. Uso o termo potencializar no sentido de abranger, de alargar, de alcançar lugares nunca antes imaginados por mim. Ao pensar o texto autobiográfico, Leonor Arfuch (2010, p. 54) salienta que, para “além do nome próprio, da coincidência empírica, o narrador é outro diferente daquele que vai narrar". Acrescento que no espetáculo Sofia -35 ocorre um movimento triplo: o narrador é diferente de quem viveu a experiência, que é diferente do ator do espetáculo e de seu processo de composição.

Sofia -35 é, dentro de tantas possibilidades, um grito, e está no lugar do extremo. Sua comicidade deixa revelar uma realidade cruel

1 Monólogo autobiográfico no qual sou ator e dramaturgo, com direção corporal de Paulo de Melo e direção vocal de Doriana Mendes. O espetáculo trabalha questões Lésbicas, Gays, Bissexuais, Travestis, Transexuais, Transgêneros, intersexuais e Queer - LGBTIQ, com foco na vida de travestis e transexuais que saem do Nordeste para o Sudeste do Brasil, em busca de uma vida menos opressora. Como contraponto, narro a primeira vez em que vi uma travesti na vida. Fomos contemplados com este espetáculo nos Editais Comunica Diversidade e Intercâmbio e Difusão Cultural, ambos do Ministério da Cultura - MINC, no ano de 2015, além do Edital das Artes Secult/Ce no ano de 2016. O espetáculo viajou sete estados, cumprindo mais de 100 apresentações. e cotidiana na vida das travestis, no seu dia a dia marginalizado, no seu simples voltar do trabalho às lembranças de sua mãe. Um contexto cruel que se manifesta na vida daquelas que atualmente no Brasil possuem uma estimativa de vida de 35 anos. $^{2}$

Esta estimativa somente reafirma o que a literatura aponta sobre a vida das travestis e pessoas trans, que é como a expulsão, a exclusão da família e amigos, as impulsiona para um espaço cada vez mais marginalizado e com direitos ceifados, diminuindo inclusive sua expectativa de vida e bem-estar. É sobre o lugar da margem que eu, como nordestino e homossexual, começarei a refletir sobre a população LGBTIQ no Brasil, apontando a extrema relevância das travestis na minha formação artística e cidadã, em contraponto ao apagamento histórico que o Estado e a sociedade civil brasileiros thes proporciona.

\section{Teatro Autobiográfico}

É muito difícil começar, o ato de projetar como algo que se lança para a frente, num terreno sobre o qual não se sabe ao certo onde o objeto irá cair. Em se tratando de um trabalho de análise da própria obra, mais especificamente o espetáculo Sofia -35, esta dificuldade latente se potencializa, tendo em vista a falta de distanciamento crítico e estético sobre uma dramaturgia que se constrói entre a primeira e a terceira pessoa. Neste projeto, o objeto que será lançado e o sujeito propositor se misturam, numa investigação que permeia o teatro autobiográfico, questões de gênero e performatividade, relevantes não apenas em meu trabalho, mas também ao teatro contemporâneo. Devo salientar aqui a necessidade que terei de citar questões pessoais, memórias, relatos, referências e atravessamentos, medos, percursos e percalços, numa escrita em que os

2 Dado extraído do site do Grupo Gay Bahia - GGB. 
principais apontamentos buscarão ser friccionados de forma que a sensibilidade da escrita não desapareça.

O projeto surge em 2007, quando, com dezoito anos de idade e em meio a minha descoberta e afirmação como homossexual, mudei de calçada ao ver uma travesti pela primeira vez na vida, na cidade de Acopiara, interior do Ceará. Ocorreu em mim uma explosão simultânea de repulsa e atração que se manifestou através do medo.

De repente lá vinha ela: alta, colorida, com uma postura ereta. Vinha andando rápido e sem olhar para os lados. 0 salto alto brilhava tanto, tanto ou mais do que seus olhos. Aquela imagem me fez estagnar na rua, meu corpo ficou gelado, em êxtase e eu não sabia explicar o porquê. Minha única reação naquele momento foi mudar de calçada. Eu gostaria realmente de poder voltar atrás e agir diferente, mas infelizmente não posso. (LOPES, 2014, p. 3)

Este fato me perseguiu até o ano de 2011. Sempre recordava da ocasião com angústia. Aquela imagem tão colorida e forte, cheia de plumas e lantejoulas, conseguiu, naquele momento, inquietar a minha forma de ver o mundo, ainda tão opaca e heteronormativa. No entanto, no ano de 2011, ao ingressar no Curso de Licenciatura em Teatro da Universidade Regional do Cariri - URCA, no Estado do Ceará, o professor Alysson Amâncio solicitou-me que compusesse uma pequena cena de uma travesti espancada por quatro rapazes numa estrada. Esta cena durava aproximadamente três minutos e fazia parte de um espetáculo denominado Deus, trabalho final da disciplina de Expressão Corpo-vocal. Ao receber o convite, primeiro neguei-me a fazer, por achar que seria complexo e que não teria capacidade de realizar o trabalho com satisfação, segundo, pelo fato ocorrido em 2007. Não me sentia capaz de abordar este tema como ator.

Passada a experiência, em 2011, comecei então a construir uma dramaturgia em que uma personagem travesti, em um pequeno quarto de uma cidade grande, expunha todos os seus problemas e dificuldades, ao chegar a uma cidade metropolitana, onde o preconceito não se manifestava de forma menos cruel. Expunha também, em momentos pontuais, a primeira vez que vi uma travesti na vida. A versão deste esquete de três páginas continuou com o nome Deus e participou de dois festivais no ano de 2012, um deles em Fortaleza, chamado Festival de Teatro da Companhia Acontece - FECTA. 0 esquete caminhava no paralelo entre as duas situações: mudar de calçada e agir com violência fisica e psicológica contra travestis.

Em 2014, já na cidade do Rio de Janeiro e como aluno transferido do Ceará para a Universidade Federal do Estado do Rio de Janeiro UNIRIO, decidi consolidar o projeto de montagem do espetáculo com o apoio de estudantes e professores desta Universidade. O percurso exposto tem extrema relevância para o debate que se segue, tendo em vista que é a partir dos encontros, dentro e fora da sala de ensaio, que a ideia do espetáculo Sofía -35 começa a germinar. É nos encontros com professores e alunos, nas conversas e depoimentos das travestis e transexuais, nas leituras feitas de antropólogos, sociólogos e psicólogos, nas referências estéticas de cineastas, dramaturgos e encenadores teatrais, na pesquisa de imagens e nas minhas mudanças e permanências também como homossexual, nordestino e artista, enfrentando a cidade grande, que o espetáculo começa a ser vislumbrado em junho de 2014.

0 presente artigo tem como principal objetivo analisar a criação dramatúrgica do espetáculo Sofia -35, monólogo em que eu, nos lugares de ator/autor/personagem, me descontruo e me reconstruo durante a peça. Busco perceber como, na dramaturgia autobiográfica do espetáculo LGBTIQ Sofia -35, realidade e ficção se relacionam na construção da personagem Sofia. 
Pretendo, a partir das minhas próprias ficções e em diálogo com a construção da personagem, identificar as tensões e imbricamentos entre os dois relatos propostos pela dramaturgia: a conversa de Sofia dentro de um pequeno apartamento com sua amiga Dayana e parte da história de vida do próprio autor. ${ }^{3}$

O teatro autobiográfico é influenciado pelo rizoma que organiza e cria significantes num sistema de conexões nem sempre conscientes em um primeiro momento, mas também pela necessidade de desterritorialização, de fuga, que também faz parte do rizoma. ${ }^{4}$ Refletindo sobre o processo do espetáculo Sofia -35, lembro da necessidade de desterritoritalizar-me em 2014, quando literalmente decido mudar para o Rio de Janeiro. Este ponto é importante, pois foi justamente o momento em que se acendeu em mim a vontade de montar este espetáculo. Ao estar longe da família e dos amigos, da cultura da minha região. Ouso dizer que o lugar de mudança é um dos fortes potenciais para a criação autobiográfica. Neste movimento de distanciar-nos de nossa terra, conseguimos perceber com mais clareza o próprio rizoma de onde viemos.

3 Evitarei utilizar aqui os termos: "quebra da quarta parede" ou "distanciamento", abordados por Bertolt Brecht, mesmo reconhecendo a importância histórica destes termos para o teatro contemporâneo, tendo em vista que as duas narrativas do espetáculo, do ator e da personagem, não migram entre razão do ator e emoção do personagem, por exemplo, mas coexistem em potência atravessando de forma direta e sensivel as duas partes.

4 Um rizoma como haste subterrânea distingue-se absolutamente das raízes e radículas. Os bulbos, os tubérculos, são rizomas. Plantas com raiz ou radícula podem ser rizomórficas em um outro sentido, inteiramente diferente: é uma questão de saber se a botânica, em sua especificidade, não seria inteiramente rizomórfica. Até animais o são, sob sua forma matilha; ratos são rizomas. As tocas o são, com todas as suas funções de hábitat, de provisão, de deslocamento, de evasão e de ruptura. O rizoma nele mesmo tem formas muito diversas, desde sua extensão superficial, ramificada em todos os sentidos, até suas concreções em bulbos e tubérculos. Há rizoma quando os ratos deslizam uns sobre os outros. Há o melhor e o pior no rizoma. (DELEUZE; GUATTARI, 1995, p. 4)
Muitos artistas criam suas obras num duplo movimento entre voltar para suas origens, sua terra, país, cidade natal e família, em direta relação com a antropofagia dos seus espaços atuais. Aspectos da potência criativa da distância podem ser encontrados nas encenações dos diretores Eugenio Barba, Pina Bausch, Peter Brook e Jerzy Grotowski, que pesquisam a relação do performer com o meio, utilizando observações e memórias de diferentes espaços como indutores de seu processo criativo. Grotowski influencia diretamente o fazer teatral de Cacá Carvalho. Numa das entrevistas do diretor paraense Cacá Carvalho à pesquisadora Wlad Lima sobre o espetáculo Hamlet: um extrato de nós, o mesmo expõe: "em todo trabalho que eu faço, eu me pergunto, como é isso em mim, em Belém? [...]. Eu queria que este espetáculo tivesse uma opinião onde o material de que ele é feito, as pessoas que o fazem, a qualidade sonora, tivessem a cara de tudo isso, de onde eu sou" (LIMA, 2005 p. 68).

Morei na cidade de Juazeiro do Norte - Ceará durante quatro anos, entre 2010 e 2014. Em 2011, comecei a cursar teatro na Universidade Regional do Cariri - URCA. Juazeiro do Norte é uma cidade que cresceu muito nos últimos cem anos devido ao turismo religioso e pelo fomento das festas em homenagem a figuras como Padre Cícero Romão, que foi padre e prefeito da cidade. Outra festa de enorme importância é a festa de Nossa Senhora das Candeias, onde as ruas ficam escuras e milhares de fiéis carregam, em procissão, uma vela na mão, criando uma imagem coletiva impressionante. Juazeiro do Norte é uma cidade em que as relações entre política e religião, sagrado e profano são muito evidentes. Este aspecto da cidade se corporifica no espetáculo Sofia -35 em algumas cenas, nas quais trato diretamente a religiosidade de grupos homossexuais $\mathrm{e}$ principalmente de travestis e transexuais que são expulsas e agredidas de grupos cristãos. 
Estes últimos deslegitimam sua religião, ao exercerem sua intolerância e preconceito:

Era lindo de se ver toda a rua escura só iluminada pelas velas. Era viado, neste dia o aquecimento global gritava amor. Aí eu fui crescendo, mudando, me transformando na própria luz e mãezinha não queria mais que eu fosse por causa dos outros (pequena pausa). Sabe o que fiz ontem? Fui na Igreja. Fui sim Dayana. Fui discreta, de preto, acendi uma vela pra mãezinha e outra pra ti porque você é sem cabeça, mas é minha irmã de coração. Bicha pára, gosto de abraço não. Quando eu estou saindo diz quem eu encontro. 0 padre puto olhando pra mim como se eu fosse um ladrão, um demônio. (LOPES, 2014, p. 2)

O coletivo, que geralmente se estabelece na arte e mais especificamente no teatro, busca não segregar, estimulando a tolerância e a diversidade sexual. Esta postura não é adotada pela maior parte dos grupos religiosos do Brasil, onde o julgamento e a coerção ainda se legitimam como fortes instrumentos de opressão para os homossexuais. Trabalhar em coletivo e com o teatro autobiográfico é ter a possibilidade de trazer estas questões para a superfície, reelaborá-las de forma sensivel através da linguagem teatral. É a possibilidade de se deixar influenciar positivamente pelo outro e não de coagi-lo.

Para Cacá Carvalho, o trabalho coletivo nos permite uma imaginação imaterial e não-formal, que se forma a partir do transbordamento de uma rede, permitindo assim tanto a sua desmontagem quanto a remontagem, de infinitas maneiras diferentes, como deve ser um devir, no vazamento de seus cheiros, de suas atmosferas (LIMA, 2005).

Relato a experiência com o coletivo porque não consigo compreender, no meu fazer artístico, a escrita de uma dramaturgia autobiográfica sem os atravessamentos deste percurso. Para a análise da dramaturgia do espetáculo Sofia -35, desconsiderar tais fato- res seria perceber o processo de forma reducionista. Cacá Carvalho nos diz que o teatro é um lugar de recuperação do ser, onde o ator pode crescer e continuar no processo de viver para conhecer (LIMA, 2005). Neste sentido, o teatro autobiográfico, onde o ator é incentivado a sensibilizar a sua percepção da vida, possibilita ao mesmo um percurso de autoconhecimento como artista, como indivíduo no mundo e como cidadão. Para o trabalho de construção da personagem, estas individualidades do processo, que se caracteriza pela pluralidade, constroem personagens mais profundos justamente pela característica híbrida de sua criação.

A experimentação do ator, para a construção da sua dramaturgia pessoal, passa necessariamente pelo seu poder de síntese no palco. Cacá parte de qualquer ponto para a sua criação, e não de um ponto de partida convencional de um texto preestabelecido. Em suas conclusões sobre o observado, no processo de montagem e nas apresentações do espetáculo Hamlet, um extrato de nós, Wlad Lima argumenta que este tipo de processo não pretende chegar ao espectador como uma estética revolucionária, entretenimento ou exposição das pessoas-atores, mas como uma forma teatral que incomoda de certa maneira, que transforma em seu estranhamento e que acorda, tanto quem faz quanto quem vê.

Desenvolver esta dramaturgia em potencial tem sido uma pretensão de alguns grupos de teatro que surgem na década de 1980 e 90 no Brasil, do teatro colaborativo, do teatro autobiográfico e do teatro documentário, todos contemporâneos, tais como o Teatro da Vertigem em São Paulo e a Companhia dos Atores no Rio de Janeiro. Alguns encenadores do século XX, como Artaud, Grotovski e Kantor, dedicaram-se incansavelmente a desmistificar a ilusão no teatro, seja ao romper a quarta-parede, por meio da quebra da ficção, ou mesmo 
através do não uso da palavra e do corpo extracotidiano.

Estas pesquisas têm em comum uma maior dedicação em relação ao trabalho do ator e à suas composições. Neste sentido, a percepção do meio no qual o ator está inserido começa a ser observada a partir de Stanislavski. Apesar deste diretor trabalhar predominantemente com a ideia de construção realista, por meio da ilusão e da quarta parede, ele é um dos grandes motivadores do trabalho de pesquisa de ator, na busca do que este pode oferecer de material pessoal para a cena. Desde a mimesis até cartas, fotografias e diários, vão sendo utilizados como material de laboratório e indutor de sensações, surgindo como pré-texto ou subtexto, para depois tornar-se texto, compreendido aqui como palavra.

Renato Cohen, em Work in progress na cena contemporânea, faz uma reflexão mais aprofundada sobre as influências deste sistema de operações, "advindo das ciências mas nas artes utilizadas prioritariamente na literatura e nas artes visuais" (COHEN, 2013, p. XXXVIII). No teatro, opera-se pela superposição de estruturas, de procedimentos gerativos, da hibridização de conteúdos, levando-se em conta o processo, o risco, a permeação, onde o entremeio criador-obra são características da origem da linguagem. Para Cohen (2013, p. 17):

Literalmente poderíamos traduzir por 'trabaIho em processo', procedimento este que tem por matriz a noção de processo, feitura, iteratividade, retroalimentação, distinguindo-se de outros procedimentos que partem de apreensões apriorísticas, de variáveis fechadas ou de sistemas não-iterativos.

Pode-se citar como exemplo deste tipo de processo, o trabalho desenvolvido pelo diretor Antonio Araújo, no Teatro da Vertigem, onde o próprio espaço não-convencional é também texto e elemento totalmente imprescindivel para a composição dramatúrgica. A montagem do espetáculo $O$ Paraíso perdido apresenta alguns pontos de convergência com o que o diretor Cacá Carvalho denomina de "Manual de Cavalaria", e é diretamente atravessado pelo que Araújo denomina de observação ativa dos seus atores, buscando aguçar a percepção por meio dos cinco sentidos, a penetração nos detalhes e o uso da máxima suspeita sobre si mesmo.

De acordo com o que Antonio Araújo chama de depoimento pessoal do ator, o que importa neste processo são os pressupostos subjetivos e individuais de cada ator, a forma como os atores se colocam diante da temática abordada. A perspectiva do depoimento pessoal constitui um dos eixos fundamentais do Teatro da Vertigem. Esta abordagem incita o ator a emitir uma crítica, uma opinião, através das mais diversas formas, para o trabalho. 0 ator do Teatro da Vertigem deve ser ativo nas proposições e não somente executar as indicações dramatúrgicas:

O depoimento pessoal não funciona apenas como instrumento de pesquisa, no caso, temática, mas também como gerador do material bruto para concretização da peça. Além de se constituir em exercício interpretativo de caráter investigatório, ele também conclama o ator a assumir o papel de autor e criador da cena, que é construída a partir do material que ele mesmo traz para os ensaios. (ARAÚJO, 2011, p. 110 , grifo do autor)

Esta busca do ator que deve sempre estar atento ao seu meio, às respostas do seu próprio corpo, ao seu trabalho, ao material coletado, ao acaso e à caoticidade contemporânea, vai aproximando cada vez mais o trabalho do ator ao do performer. Suas características ficam ainda mais presentes tanto no percurso quanto no espetáculo. Esta foi uma busca constante da minha parte no espetáculo Sofia -35, em paralelo a uma temática que me atravessava diretamente como homossexual e nordestino, apesar de não ter consciência destes pontos 
em comum, no início do processo. No Teatro da Vertigem, este tipo de ator é chamado de ator-pensador, ator performer ou a(u)tor.

Acredito que, por mais que pareça dificil, e realmente não nego que seja, é através do depoimento pessoal, ou mesmo do teatro autobiográfico, que o ator consegue alcançar um lugar de entrega e sinceridade rara de ser obtida. O exercício do depoimento pessoal compreende desde relatos e objetos da infância, até a ideia pessoal do que seria o paraíso ${ }^{5}$ para o ator (ARAÚJO, 2011).

A obra $O$ espaço biográfico: dilemas da subjetividade contemporânea, de Leonor Arfuch (2010) fricciona ainda mais o debate, pois por vezes induzimos que o autor e o personagem criado seriam a mesma pessoa, tendo assim as mesmas características no teatro autobiográfico. Arfuch traz uma discussão muito pertinente para pensarmos o fazer teatral autobiográfico por meio da ruptura proposta por Mikhail Bakhtin, ao afirmar que: "não há identidade possivel entre autor e personagem, nem mesmo na autobiografia porque não existe coincidência entre experiência vivencial e 'totalidade artística"' (ARFUCH, 2010, p. 55).

Então, por mais que eu queira entender os limites entre uma criação autobiográfica e a construção do espetáculo Sofia -35, é possivel afirmar o fracasso desta tentativa, tendo em vista que meu eu a(u)tor, criando uma linguagem artística, já no processo de escrita do texto, é distinto do meu eu em experiência.

Não se tratará então de adequação, de uma "reprodução" do passado, da captação "fiel" de acontecimentos ou vivências, nem das transformações "na vida" sofridas pelo personagem em questão, mesmo quando ambos - autor e personagem - compartilham o mesmo contexto (ARFUCH, 2010, p. 55).

5 O paraíso do ponto de vista pessoal; o paraíso como infância; o paraíso do ponto de vista do outro; o paraíso como encontro consigo mesmo; o paraíso como vivência e experiência do sagrado. (ARAÚJO, 2011, p. 11)
Podemos entender então, na literatura, a autobiografia como estando também em percurso. Não um trajeto bilateral entre emissor e receptor, mas a consideração deste trajeto como um "devir da identidade, como um trajeto sempre aberto à diferença, que ressignifica constantemente as instâncias do autorreconhecimento" (ARFUCH, 2010, p. 126)

Um devir da diferença, onde não importam apenas os lugares de chegada e de partida, mas os entremeios de todo o processo de escrita e de concepção da obra artística. Neste sentido, o dramaturgo não é o mesmo que experiencia, apesar de ambos reencontrarem-se em muitas ocasiões.

\section{Dentro e fora da cena: questões de gênero e teatro autobiográfico}

Sofia Hathaway, personagem que surge como um botão de rosa, que respeita o processo de construção de um ator e dramaturgo que escreve os seus próprios percursos e ficções. Sofia é uma personagem que age como aquela flor de cheiro enjoativo chamada dama da noite, que espera a noite chegar para desabrochar, aguarda e respeita o seu momento de entrada. Foi assim por todo o processo, desde 2011 até 2014, em Sofia não só aparece como também reivindica o seu lugar, apodera-se de seu nome e de sua identidade, questionando este dramaturgo e ator com quem divide o espaço do apartamento já completamente apertado. 0 nome Sofia vem da palavra filosofia, que quer dizer sabedoria. Já seu apadrinhamento Hathaway, vem da atriz nova-iorquina Anne Hathaway, referência visual a que guarda grande respeito. 0 contraponto entre a sabedoria, os contos de fadas e utopias de uma artista em ascensão dá-se com o espaço cênico claustrofóbico de um pequeno apartamento, onde os relatos e os percalços cotidianos, o medo e as lembranças de um passado nostálgico vão se justapondo. 
De acordo com as pesquisas, observações e vivências, na sala de ensaio, o paralelo traçado entre o cotidiano opressor e a capacidade de criar fabulações, de sonhar dentro de um pequeno apartamento, eram fortes antagonismos a serem trabalhados na construção da personagem e da dramaturgia. Como travesti que não aceita a sociedade machista na qual se encontra, Sofia questiona, em suas ações e discursos, a sociedade cruel em que as diferenças são ceifadas, postas à margem, e na qual as minorias sofrem diariamente manifestações de ódio e repulsa.

É importante perceber aqui como as relações entre as lutas LGBTIQ e feministas se apoiam historicamente e como a ideia de gênero é friccionada e ressignificada nestes dois campos. Para Judith Butler (2015), os sistemas jurídicos e de poder impõem à mulher um fardo histórico que the atribui ações e afazeres específicos, as tradicionais "coisas de mulher", o lugar da cozinha, a responsabilidade para com os filhos, que constituíram historicamente para a mulher não uma opção, mas uma obrigação, na maior parte das configurações sociais, a partir do surgimento da sociedade patriarcal. Em paralelo, foi disseminada a coexistência de uma indisposição feminina sem precedentes, que não disfarça o discurso de que a mulher seria "naturalmente indisposta".

Ser homem, ao contrário, pressupõe virilidade, força de trabalho, poder intelectual e de decisão como dons inatos. Segundo a autora, "Foucault observa que os sistemas jurídicos de poder produzem os sujeitos que subsequentemente passam a representar" (BUTLER, 2015, p. 18 , grifo da autora). Esta produção dá origem e é o centro das configurações de gênero, onde se fortalece uma visão binária e heteronormativa da sexualidade.

Butler critica as formulações de sexo, gênero e desejo, como estando ligadas a uma formação específica de poder, a partir da retomada do conceito de genealogia de Nietzsche, por Foucault. De acordo com Butler:

As noções jurídicas de poder parecem regular a vida política em termos puramente negativos - isto é, por meio da limitação, proibição, regulamentação, controle e mesmo 'proteção' dos indivíduos relacionados àquela estrutura política, mediante uma ação contigente e retratável de escolha. Porém, em virtude de a elas estarem condicionados, os sujeitos regulados por tais estruturas são formados, definidos e reproduzidos de acordo com as exigências delas. (BUTLER, 2015, p. 18)

Este debate atravessa diretamente os debates mais recentes dos grupos feministas, onde o sujeito criado pelas instituições de poder e condicionado pelas mesmas reproduz o patriarcado e a heterossexualidade compulsória deliberadamente. As contribuições dos estudos sobre genealogia nos auxiliam na compreensão e leitura de como os sistemas jurídicos de poder criam o sujeito que passam a representar. Esta possibilidade alarga o debate sobre gênero e sexualidade, ao passo que desnaturaliza o modus operandi delicado, submisso e frágil da mulher, aprofundando o discurso sobre a impossibilidade de uma identidade genuína.

A ideia de gênero como universal segue em comunhão com a ideia da possibilidade de um patriarcado também universal que se legitima. É pertinente perceber que esta forma de compreender as diversas sociedades e suas relações é extremamente reducionista e deslegitima a pluralidade cultural, a diversidade e as mais distintas organizações sociais, além da individualidade de cada pessoa. Estas construções dos sistemas políticos de poder fortaleceram durante séculos a hierarquia do homem sobre a mulher, no duplo da lei que cria o indivíduo para representá-lo. Podemos falar então de fases do movimento feminista que se alargam no tempo, a partir dos estudos 
e análises sobre gênero, sexualidade e desejo, em relação direta com as leis e as instituições de poder.

De acordo com Butler, a formulação de sexo como tendo um caráter imutável é contestável e seu binarismo talvez seja tão culturalmente construído quanto a ideia de gênero. 0 gênero não deve ser tido como inscrição cultural de significado para um sexo previamente dado. 0 gênero não está para a cultura assim como o sexo para a natureza, não é um meio pelo qual as ideias de "natureza sexuada" ou "sexo natural" são produzidos e estabelecidos (BUTLER, 2015). Segundo a autora:

A noção binária de masculino/feminino constitui não só a estrutura exclusiva em que essa especificidade pode ser reconhecida, mas de todo modo a 'especificidade' do feminino é mais uma vez totalmente descontextualizada, analítica e politicamente separada da constituição de classe, raça, etnia e outros eixos de relações de poder, os quais tanto constituem a 'identidade' como tornam equívoca a noção singular de identidade. (BUTLER, 2015, p. 22).

Esta fricção fica evidente nos grupos LGBTIQ e na sua historicidade. Os homossexuais subvertem não somente as questões de gênero e sexo, mas também o seu discurso quando, em sua performatividade cotidiana, rompem com a forma heteronormativa de compreensão do mundo, de construção das leis e de legitimação do poder. A possibilidade da articulação de gênero como binária, encontra, tanto no feminismo quanto no movimento LGBTIQ, a resposta à sua impossibilidade. A lógica binária que fundamenta as relações sociais e de construção das leis fortalece discursos sexistas e o domínio histórico dos homens heterossexuais sobre as mulheres heterossexuais e os homossexuais. No espetáculo Sofia -35, ao receber um telefonema comunicando a morte da mãe, a personagem Sofia deixa claro o quanto esta opressão pode ser cruel:
(Ao telefone) Alô? Marlene? Como é que tu tá? Tô sabendo, este seu caso amoroso já é antigo prima. Sei, um dia você consegue amarrar este caso. Mas me diz, e o povo aí de casa, tem notícias? Sim, tô escutando (pausa). Não brinca comigo Marlene (pausa). Eu vou à rodoviária comprar uma passagem pro primeiro ônibus... Ah tá, meus irmãos mandaram avisar que vai ter muita gente aí né? Eles não querem que eu vá? Dá um beijo nela por mim prima. Tenho saudades de tudo. (LOPES, 2014, p. 6)

Este tipo de reação é comum no Brasil. Volto minha atenção para a região Nordeste, por Sofia ser uma personagem nordestina que migra para o Rio de Janeiro. É recorrente a não aceitação e a repressão por parte da família, principalmente porque ter um irmão homossexual ou travesti significa desonra numa sociedade predominantemente heteronormativa.

Butler defende que a articulação de uma identidade em modelos culturais disponiveis estabelece uma definição que exclui o surgimento de novas identidades. Já as práticas fundacionistas não têm como objetivo a expansão ou transformação das novas identidades. (BUTLER, 2015). Sobre a matriz heterossexual, a autora desenvolve:

A 'presença' das assim chamadas convenções heterossexuais nos contextos homossexuais, bem como a proliferação dos discursos especificamente gays da diferença sexual, como no caso de Butch e femme (papéis masculinos e femininos eventualmente assumidos nos relacionamentos lésbicos) como identidades históricas de estilo sexual, não pode ser explicada como a representação quimérica de identidades originalmente heterossexuais. (BUTLER, 2015, p. 66, grifo da autora).

Neste sentido, a comparação feita por Butler da cópia para o original torna-se pertinente para percebermos como as leis podem se estabelecer a partir de convenções heterossexistas mesmo em contextos homossexuais. Em outras palavras, não se deve cair no estigma de que, aos homossexuais, cabe uma 
origem heterossexual ou que a identidade e a sexualidade gay esteja diretamente relacionada a constructos heterossexistas. Dado o exposto do pensamento da autora, percebe-se a relevância de se questionar as convenções heterossexistas, enfrentando assim as representações da identidade como signos fechados. Este enfrentamento possibilita abrir o significante e a pluralidade de sentidos para se refletir sobre gênero, sexo e identidade. Para a autora:

Se alguém 'é' uma mulher, isto certamente não é tudo o que este alguém é. O termo não logra ser exaustivo, não porque os traços predefinidos de gênero da 'pessoa' transcendam a parafernália específica do seu gênero, mas porque o gênero nem sempre se constitui de maneira coerente e consistente nos diferentes contextos históricos, e porque o gênero estabelece interseções com modalidades raciais, classistas, étnicas, sexuais e regionais de identidade discursivamente constituídas. (BUTLER, 2015, p. 21)

Em se tratando do contexto brasileiro, a vida dos LGBTIQ merece uma atenção especial. Travestis e transexuais sofrem perseguições extremamente pesadas, em seu cotidiano, praticadas pela população e por instituições que deveriam ampará-las. 0 primeiro grande confronto estabelece-se dentro da família, mas é na escola que acontecem os piores relatos. Ser homossexual no Brasil ainda é constituir-se entre legitimação da sua identidade e a sociedade heteronormativa que repreende e caça qualquer tipo de "desvio" de seu eixo. Numa fala evocativa, relembrando sua relação com a mãe, Sofia descreve:

Ah bicha, mãe é mãe, né? Depois de mãe é mãe de novo. Oito filhos e tinha amor que sobrava. Esta sim foi pro céu de Champagne na mão querida, primeira classe. Mãezinha queria me ver sendo alguém na vida. E não sonhava pouco. Me pedia pra fazer medicina (pequena pausa). Imagina bicha: - 'Doutora Sofia, por favor comparecer à sala de cirurgia'. la ser escândalo Dayana, imagina eu causando nos corredores do hospital? Eu iria revolucionar o Brasil meu amor. (LOPES, 2014, p. 6)

A falta de instrução escolar e de uma educação que permita abordar a diversidade sexual no Brasil acaba fortalecendo a não aceitação histórica de homossexuais, travestis e transexuais. De acordo com Márcia Cristina Brasil Santos, em seu artigo intitulado Quando a escola é um inferno... (2013), a escola em muitas ocasiões exclui os "desviantes", retirando-lhes o direito de uma educação formal e ceifando a possibilidade de inserção no mercado de trabalho, alargando ainda mais as disparidades sociais. As travestis sofrem com isto ainda mais, tendo em vista que no Brasil é pequeno o número de travestis e transexuais que conseguem concluir o ensino secundarista (SANTOS, 2013). A muitas delas, resta trabalhar como cabeleireiras e manicures, com performances artísticas ou, em sua maioria, com a prostituição. A ausência de oportunidades acaba estabelecendo no imaginário coletivo estigmas pautados em dados sensacionalistas que colocam os homossexuais como grupos de risco de doenças sexualmente transmissiveis, tais como a Sindrome da Imunodeficiência Adquirida - AIDS. Como Butler observa:

Não só a doença é representada como a 'peste gay', mas com a reação histérica e homofóbica da mídia à doença registra-se a construção tática de uma continuidade entre o status poluído do homossexual, em virtude da violação da fronteira que é o homossexualismo e a doença como modalidade de poluição homossexual. (BUTLER, 2015, p. 228, grifos da autora)

Todos estes fatores atravessam diretamente a vida de travestis e transexuais, e mais, articulam a possibilidade de sua repressão $e$ expulsão dos mais diferentes espaços. A cada passo em que o homossexual se aproxima da ideia do feminino construído no imaginário brasileiro, o preconceito é potencializado. Em se tratando da vida de travestis e transexuais, 
o preconceito estabelece-se de forma direta, por meio de agressões morais e físicas, muitas vezes em comum acordo ou praticada pela própria polícia.

O Grupo Gay da Bahia (GGB) divulga um relatório anual do homicídio de homossexuais, travestis e transexuais. A expectativa de vida de uma travesti no Brasil é de 35 anos. Em 2012, foram assassinadas 128 travestis no país, do total estimado de cinquenta mil travestis. Ou seja, 1 em cada 400 travestis são assassinadas todos os anos no Brasil, e estima-se ainda que $90 \%$ trabalhem na prostituição. ${ }^{6}$ Levando-se em consideração este número desenfreado de mortes, a cada 26 horas uma travesti é assassinada no Brasil.7 A transfobia, movida na maior parte dos casos por um discurso de ódio, revela-se de forma muito clara no contexto brasileiro, em detrimento de um Estado que não assegura os direitos mínimos de segurança dos seus cidadãos.

Apesar dos importantes resultados alcançados pelo Brasil nos últimos anos, no que se refere à luta pelos direitos LGBTIQ, o comportamento homofóbico ainda é praticado pela maior parte da sociedade brasileira. Para Ana Maria Carvalho Capucho e Ana Maria de Viola, no artigo intitulado Direitos humanos: questões atuais sobre a violência contra LGBTTT (2014), o ato de discriminar surge de uma necessidade competitiva, haja vista que tal ato se manifesta pelo desejo de se reduzirem as perspectivas de uns em beneficio de outros.

6 Dados extraídos de pesquisas divulgadas pelo Grupo Gay da Bahia - GGB. Publicado em 10 de janeiro de 2012.

7 O nome do espetáculo Sofia -35 , faz referência à estimativa de vida de travestis e pessoas trans no Brasil. Esta estimativa de 2012 nos chocou muito em pesquisa e funciona no espetáculo como uma contagem regressiva disparada na própria peça onde Sofia expõe este dado. O relatório mais recente do GGB foi publicado no ano de 2016, mostrando que o número de mortes de LGBTIQ tem aumentado, contabilizado 340 mortes no ano, dentre as quais 130 no mínimo são travestis e transexuais. Dados extraídos de pesquisas divulgadas pelo Grupo Gay da Bahia (GGB). Publicado em 30 de dezembro de 2016.
Os interesses de alguns, que vão de encontro à igualdade dos grupos sociais, acabam confrontando os interesses de outros que detêm o poder e se esforçam pela manutenção do status quo. É uma dinâmica perversa que historicamente exclui os grupos fragilizados, e a tentativa de mudança cria resistência daqueles grupos que se beneficiam diretamente desta exclusão. Neste sentido, usa-se a grande mídia e as próprias instituições de poder para difundir os discursos homofóbicos e transfóbicos (CAPUCHO; VIOLA, 2014).

A intolerância é a palavra de ordem quando o assunto é a causa LGBTIQ no Brasil, que lidera todas as estimativas, como o país com mais casos de homicídio de homossexuais no mundo. De acordo com dados do Grupo Gay da Bahia, a cada cinco assassinatos de homossexuais em todo o mundo, quatro deles acontece no Brasil. ${ }^{8}$ De acordo com Capucho e Viola:

Declarações polêmicas sobre homossexuais atingem a sociedade brasileira como um todo. A Comissão de Direitos Humanos da Câmara foi presidida pelo polêmico deputado Marco Feliciano que fez declarações sobre os homossexuais como: 'a podridão dos sentimentos dos homoafetivos leva ao ódio, ao crime, à rejeição'. (CAPUCHO; VIOLA, 2014, p. 8)

Em seu livro Travesti - Prostituição, sexo, gênero e cultura no Brasil (2008), o antropólogo sueco Don Kulick, que pesquisou e conviveu com travestis do Pelourinho, em Salvador - BA na década de 1990, aponta, em seus relatos, entrevistas e diários, características marcantes das travestis dentro e fora do seu grupo, além da relação da sociedade com as mesmas, num sistema político que, segundo o autor, é marcado pela rotinização do sofrimento de maior parte da população em paralelo a um sistema sociopolítico corrosivo e caracterizado pela descriminação de classe e etnia.

8 Dados extraídos de pesquisas divulgadas pelo Grupo Gay da Bahia - GGB. Publicado em 10 de janeiro de 2013. 
Kulick consegue não romantizar a imagem da travesti no contexto brasileiro, buscando sempre um olhar muito coeso e factual, que serviu de grande referência para a minha percepção da travesti nordestina e me servirá novamente agora, para levantar algumas questões, trajetos e imaginários que atravessaram diretamente a construção da personagem Sofia.

Kulick (2008) evidencia que em nenhum outro lugar a violência é tão direta quanto no cotidiano de travestis e transexuais no Brasil. As travestis aproximam-se do universo compreendido como feminino, em suas maquiagens, cabelos, formas e ações, mas claramente não são mulheres e causam uma impressão incongruente. Quando saem à rua, principalmente de dia, horário em que geralmente evitam se expor, estas impressões refletem um misto de olhares hostis e libidinosos, por parte da população heteronormativa de Salvador. Os tipos de violência incluem geralmente espancamentos por parte de gangues de jovens, apedrejamentos e disparos de armas de fogo. Normalmente os praticantes não são identificados nem detidos; e, quando o são, recebem penas leves da justiça (KULICK, 2008).

Kulick (2008) constrói o lugar narrativo de um autor que transita entre a percepção aguçada, na riqueza dos detalhes, e a atenção ao contexto no qual estava inserido. Consegue, aos poucos, conquistar a confiança das travestis do Pelourinho e em algumas desperta até a atração, tendo em Banana (apelido de uma delas), uma de suas maiores confidentes. Sobre as travestis no Brasil, discorre:

O termo 'travesti' deriva do verbo 'Transvestir', que pode ter o sentido de vestir roupas do sexo oposto (ou cross-dress, em inglês). Porém, as travestis não se caracterizam apenas por usar roupas de mulher. A principal característica das travestis de Salvador e de todo o Brasil, é que elas adotam nomes femininos, roupas, penteados e maquiagens femininos, pronomes de tratamento, além de consumirem grande quan- tidade de hormônios femininos e pagarem para que outras travestis injetem até 20 litros de silicone industrial em seus corpos... A despeito de todas estas transformações, muitas das quais irreversiveis, as travestis não se definem como mulheres. (KULICK, 2008, p. 21, grifo do autor).

Esta característica apresenta-se muito fortemente no discurso da personagem Sofia. Em vários momentos da peça, Sofia deixa claro que sua intenção não é nem nunca foi ser mulher. A personagem sonha com contos e princesas fictícias, muito mais por não ter referência nenhuma de travestis felizes em seu imaginário. Sofia mantém, por vários momentos no espetáculo, este imaginário fantasioso que vai sendo ceifado por lembranças e recordações de seu cotidiano, e apresentado muitas vezes de forma amargurada. A alegria e a lágrima, a tragédia e a comédia conversam na linha tênue, desenhando a justaposição de relatos que compõem esta narrativa.

Quando reflito sobre o processo e me pergunto em que medida a personagem surgiu de ficções, de desejos, do inconsciente ou dos próprios relatos, de experiências buscadas com a equipe do espetáculo e laboratórios, me dou conta de que não há a possibilidade de medir quantitativamente e mesmo se o fosse, não seria o meu interesse. Este está situado muito mais no lugar da autobiografia, na performatividade e nos discursos de gênero como potências de construção do espetáculo, de uma ficção ou de uma representação onde estas três palavras-chave deixam claro um percurso artístico. o lugar de calçada, o lugar de encontro, a pausa, a mudança de calçada, são narradas pelo ator e Sofia que dividem este mesmo apartamento, amparando-se mutuamente e por vezes também desentendendo-se.

Kulick (2008) discute algumas questões que influenciam diretamente a construção dramatúrgica, como é o caso do carnaval, onde a inversão de gênero faz parte do imaginário dos 
brasileiros. Mesmo com casos de violência registrados, os números neste período são muito inferiores aos do restante do ano no Brasil. Travestis aproveitam para se montar, sair na rua tranquilamente e as que vivem da prostituição também aproveitam o feriado para trabalhar.

No artigo A Carnavalização e o riso segundo Mikhail Bakhtin, Claudiana Soerensen (2011) descreve e analisa as ideias de Bakhtin sobre o carnaval na Idade Média, no Renascimento e discute como os conceitos de carnavalização e riso vêm se transformando. De acordo com a autora:

Na concepção de Bakhtin a carnavalização não é um esquema externo e estático que se sobrepõe a um conteúdo acabado, mas uma forma flexível de visão artística, uma espécie de princípio holístico que permite descobrir o novo e o inédito. O carnaval na concepção do autor é o locus privilegiado da inversão, onde os marginalizados apropriam-se do centro simbólico, numa espécie de explosão de alteridade, onde se privilegia o marginal, o periférico, o excludente. 0 espetáculo carnavalesco - sem atores, sem palco, sem diretor - derruba as barreiras hierárquicas, sociais, ideológicas, de idade e de sexo. (SOERENSEN, 2011, p. 320)

De acordo com Soerensen (2011), Bakthin entende que, desde a Idade Média, o carnaval vem sendo a oportunidade para se revelar os aspectos mais profundos da realidade cotidiana, aqueles que talvez sejam perturbadores demais para se mostrarem abertamente em outras épocas. "Ele perpassa a esfera artística do espetáculo teatral e situa-se nas fronteiras entre a arte e a vida. Na realidade, é a própria vida apresentada como elementos característicos da representação e do jogo teatral vivido como vida real" (Soerensen, 2011, p. 322). Nesta premissa, a máscara no carnaval não constituiria um simples adorno de uma fantasia, pelo contrário, tinha o forte significado de mudança, de transformação. A máscara trazia intrin- secamente "a alegria das alternâncias, [...] a alegre negação da identidade e do sentido único" (Soerensen, 2011, p. 328). o carnaval vem se legitimando assim, num período em que a relativização da verdade e do poder dominante tem sido constante. 0 riso, neste âmbito, vem para ridicularizar tudo o que se constitui como imutável e cristalizado. (SOERENSEN, 2011). Em se tratando do contexto do carnaval brasileiro, travestis e transexuais ganham passe livre somente nesta época, onde a própria sociedade questiona seus desejos, seus corpos e as instituições de poder. No espetáculo, em uma conversa com a sua companheira de quarto Dayana, Sofia argumenta:

Tá chocada Dayana? Por que esta cara? Tu não percebeu que a nossa vida não importa? As pessoas acham que seria melhor limpar a rua da nossa existência. Tão mais fácil, tão mais bonito: de um lado, os homens, do outro lado, as mulheres e as travestis como nós, viram purpurina, e somem depois do carnaval, como numa quarta-feira de cinzas. É ou não é? (LOPES, 2014, p. 9)

Kulick (2008) surpreende-se com o enorme número de travestis e transexuais no Brasil, bem como com o movimento de migração destas do interior para as capitais do Nordeste e ou para o eixo Rio de Janeiro - São Paulo. Este número, no entanto, não se potencializa em políticas públicas, em acesso à educação e ao emprego. Este reflexo da década de 1990 perpetua-se ainda hoje, quando constatamos que grande parte de travestis e transexuais tem que recorrer à prostituição para sobreviver. 0 problema está na impossibilidade de outras formas de subsistência, na falta de oportunidades de inserção social e na violência que ainda persevera.

Tanto no teatro contemporâneo, onde temos a possibilidade de reelaborar os nossos próprios discursos na cena, sobrepondo imagens, contrastando as mais diversas tecnolo- 
gias, discordâncias e dúvidas, quanto no cotidiano das travestis e transexuais, percebe-se a reconfiguração do discurso de gênero, onde os verbos estar e permanecer são premissas. Ser travesti no Brasil ainda é um ato de reconfiguração em gerúndio, onde as mudanças são conquistadas aos poucos e a cada dia, tanto na individualidade quanto na luta política organizada.

As reconfigurações ficavam cada vez mais claras para mim, desde o episódio em que mudei de calçada até os primeiros estudos para a construção da personagem. O medo ainda coexistia com as relações de encantamento e curiosidade. Este processo de desconstrução é diário e conta com a percepção de atitudes individuais que cometia, mesmo sendo artista e estudante universitário. Como observa Kulick:

A caracterização de travestis meramente como 'invertidos' é incapaz de transmitir ou transcrever adequadamente a repulsa e o medo profundos que elas podem despertar em muitos brasileiros. É incapaz tampouco, de explicar a atração eletrizante que as travestis provocam onde quer que estejam. (KULICK, 2008, p. 27)

Percebe-se a importância da obra de Kulick (2008) no contexto brasileiro da década de 1990 e do debate sobre os grupos LGBTIQ no Brasil, na tentativa de defender que as travestis ampliam a ideia de gênero e sexualidade no país, pois "dizer que travestis completam ou aperfeiçoam as mensagens ou os discursos de gênero presentes na sociedade brasileira é muito diferente de dizer que travestis invertem tais mensagens" (KULICK, 2008, p. 26).

Travestis são comumente representadas em telenovelas, filmes, espetáculos teatrais, na literatura contemporânea, mas sempre de forma marginalizada, promíscua e sexualizada. As travestis eram apresentadas para mim muito mais neste lugar do que na busca de um contraponto sensivel e aprofundado. Nos encontros para a montagem do espetáculo, que aconteciam três vezes por semana na Universidade Federal do Estado do Rio de Janeiro - UNIRIO, muito foi debatido entre mim e toda a equipe ${ }^{9}$ em relação à vida das travestis e sobre quem era esta personagem Sofia, que começava realmente a se legitimar. Mesmo com a escolha de não representá-la como prostituta, era recorrente dentro da sala de ensaio a dificuldade de perceber a travesti fora do lugar da prostituição. Para alguns companheiros de equipe, ainda parecia inverossimil pensar a travesti fora deste contexto. Todas estas leituras foram atravessando diretamente o processo de escrita e reescrita dramatúrgica que acontecia praticamente em paralelo com os ensaios.

Sofia traz em seus discursos e falas, particularidades vividas e presenciadas por mim dentro do contexto no qual me insiro. É recorrente na minha região, por exemplo, a família não aceitar os filhos homossexuais. O Nordeste apresenta um machismo ainda muito forte, resquício de modelos políticos que permanecem. A não aceitação não acontece na minha família, mas aconteceu com muitos amigos próximos do interior, em razão de suas orientações sexuais. Grande parte dos homossexuais e transexuais mudam-se para a cidade grande na esperança de encontrar um cenário menos complexo e opressor. Este movimento ocorre fortemente no meio LGBTIQ da década de 1990, onde homossexuais, travestis e transexuais migram do Nordeste para o eixo Rio de Janeiro - São Paulo, em busca de uma melhor qualidade de vida.

o cuidado de fazer com que a própria plateia não mudasse de calçada assim como o ator, reconfigura a cena em vários momentos. Depois que Sofia narra e vive no corpo a cena de seu próprio espancamento e violação,

9 Direção vocal: Doriana Mendes; Direção Corporal: Paulo de Melo; Figurino e cenografia: Paloma Dantas, Carla Costa, Natália Mathias e Beatriz Magno; Iluminação: Mariana Machado e Maciel Tavares; Caracterização: Julia Bravo; Confecção de bonecas: Thaisa Violante. 
numa estrada deserta, praticados por quatro homens, a personagem revive as memórias do ator ao escrever este texto, onde, no lugar de dramaturgo, narra os dilemas da sua escrita:

Ele mentiu. Só digo a vocês que toda esta história não foi por este caminho, mas quando ele estava escrevendo este texto, teve medo. Medo de que assim como ele mudou de calçada, vocês todos também mudassem, pulassem para o outro lado da rua. Ele teve medo de que eu constrangesse alguém estando assim: praticamente sem roupas. Pensando nisto, ele resolveu que agora eu vestiria uma bata para causar o mínimo de desconforto possivel. Agora ele acreditou que eu poderia continuar. (LOPES, 2014, p. 09).

Sofia fecha-se em praticamente todas as cenas dentro do seu pequeno apartamento. Acha extremamente dificil o simples fato de ir de casa para o trabalho. A solidão é por muito uma constante na sua vida, tendo em vista todos os traumas que a rua lhe traz.

No contexto de Salvador analisado por Kulick (2008), as travestis não eram alvo somente de violência, xingamentos e agressões, mas também de olhares libidinosos que vinham por parte de homens e de mulheres. Todavia, se muitos demonstravam sua atração abertamente, a grande maioria lhes era hostil. As travestis de Salvador tinham que, a todo o momento, reafirmar o seu lugar e o direito de ocupação do espaço público, tendo que lidar com este duplo de atração e repulsa.

Entre o lugar de representação cotidiana e a performance artística, pode-se citar Esther Newton, que, em seu livro Mother camp: female impersonators in America (1972), consegue de forma objetiva perceber a relação dos homossexuais entre o gueto e o show business, nos Estados Unidos, em 1960. Sobre a efervescência das lutas das minorias, Newton observa a hierarquia e a verticalidade no cotidiano dos homossexuais e nas suas performances enquanto drag queens, com certo reconhecimen- to no meio LGBTIQ, em paralelo à organização das lutas e de legitimação do movimento LGBTIQ como resistência (NEWTON, 1972).

Newton apresenta nesta obra a relação da luta dos homossexuais contra uma força heterossexual subjacente intacta nos Estados Unidos. A autora também antecipa alguns apontamentos feitos por Kulick (2008) na obra Travesti..., quando analisa a representação do corpo homossexual no cotidiano e no cinema. Salienta que "O homem musculoso e a drag queen são gêmeos. 0 se fazer acreditar masculino e o se fazer acreditar feminino" (NEWTON, 1972, p. XII, tradução minha). ${ }^{10}$ Pode-se perceber aqui a construção das identidades em estreita relação com o corpo do indivíduo e sua manipulação.

Os estudos sobre a subjetividade e a performatividade de gênero pretendem apontar que até o corpo, compreendido como masculino ou feminino, é uma construção que nos é colocada como pré-discursiva, tanto no cotidiano quanto nos espetáculos de drag queen. A autora faz críticas inclusive à escolas e universidades que reproduzem os sistemas políticos sem problematizá-los.

De acordo com Newton (1972), para o espectador da rua ou do palco, nos Estados Unidos, a homossexualidade mancha a possibilidade deste indivíduo ser $100 \%$ americano, tendo em vista que este título está carregado de valores que dizem respeito ao "masculino e feminino" compreendido dentro de um ideal heteronormativo. Este pressuposto exclui portanto o homossexual como cidadão efetivamente norte-americano. Na performance drag, todas estas questões se potencializam. Homens homossexuais que se vestem de mulheres para performar, dublar, imitar, satirizar, entreter e emocionar, em baladas e festas LGBTIQ, se legitimam como o símbolo de resistência gay, de sua capacidade e criatividade. Em contra-

10 "The muscle man and the drag queen are true Gemini: the make-believe man and the make-believe woman". (NEWTON, 1972, p. XII) 
partida, carregam os maiores estigmas na sociedade heteronormativa, sendo acusados de invertidos ou promíscuos sexuais (NEWTON, 1972). Percebemos aí como o gênero se articula a partir do lugar da recepção, salientando que quanto mais o gay se aproxima da ideia cristalizada do feminino, mais ele é rechaçado pela sua comunidade, e em contrapartida é mais revolucionário dentro de seu contexto, como indivíduo que representa e simboliza o seu grupo, ao mesmo tempo em que rompe com o meio heteronormativo. Na cena 11, Sofia fala sobre o lugar da performance:

Quando eu faço uma dublagem eu me sinto num lugar sagrado. Pra mim meu palco é meu templo. Todas essas pessoas vendo as cores, os efeitos, cantando juntas músicas de amor ao outro. Existe igreja melhor que esta Dayana? A igreja das travestis dos primeiros dias. É aqui, no palco, que eu me sinto conectada com Deus. (LOPES, 2014, p. 7)

Newton (1972), assim como Kulick (2008), argumenta que alguns homossexuais sentemse fora da sociedade somente pelo ato sexual, em contraposição a outra parcela que se vê totalmente fora da sociedade vigente. A visão do homossexual como alguém totalmente marginalizado pela sociedade tem sido a mais difundida historicamente para o espectador heterossexual.

Ao pensar em recepção, remeto-me ao imaginário, também condicionado pelas leis e pelo poder que cristalizam e sufocam as mais diversas possibilidades de composição e compreensão do real. A arte está no lugar justamente de problematizar o que seria tido como tradição. Neste sentido, o lugar ativo do espectador do espetáculo teatral vem sendo discutido fortemente no decorrer do século XX. Antonin Artaud é um grande exemplo de teórico teatral que percebe a morte da palavra e busca um lugar de sensibilidade que não se baseia em significados fechados. Outro exemplo claro é Bertolt
Brecht, que, pelo distanciamento e teatro épico, também propõe uma metodologia que foge aos padrões realistas, quando seu próprio ator se distancia da cena para refletir sobre a mesma.

Em $O$ espectador emancipado, Jacques Rancière (2012) admite o lugar ativo do espectador na construção da obra, em contraposição ao modelo clássico teatral do século XVIII, onde o teatro deveria funcionar como um espelho ampliador em que os espectadores eram convidados a ver, no formato ficcional, os comportamentos, virtudes e vícios do homem. Rancière critica esta ideia, quando aponta que a política da arte não pode resolver seus paradoxos, por assim dizer, fora do seu campo, ou mesmo tomando como pressuposto o campo do "real". A seu ver não existe real, mas sim composições da realidade, a partir de um objeto de ficção, que relacionam o dizivel, o visível e o factivel. A ideia de arte e política não se constrói, segundo o pensador, como a passagem da ficção para a realidade, mas como duas maneiras de se construir ficções (RANCIÈRE, 2012).

A partir desta perspectiva, pode-se perceber a potência do teatro autobiográfico como forma de composição sensivel que surge das minhas próprias ficções, em diálogo com a construção da personagem, que se aprofunda e se deixa atravessar a partir dos dois relatos: sua conversa dentro de um pequeno apartamento com sua amiga de quarto Dayana e a história de vida do próprio autor.

Todas as composições de realidade foram buscadas e compartilhadas em sala de ensaio. Imagens, vídeos, documentários, corporeidades, performances, relatos e reportagens. Muito mais que somente pela palavra, este material imagético e humano influenciou diretamente o processo, onde as várias versões do texto chegavam, editavam e redescobriam as partituras, marcações e intenções daquela realidade que se manifestaria na cena. É oportuno dizer que, ao passo que a personagem 
surgia na cena, suas lembranças, inquietações e desejos influenciavam diretamente minha escrita, reconfigurando a dramaturgia e a encenação. Para Rancière: “A eficácia da arte não consiste em transmitir mensagens. Ela consiste sobretudo em disposições dos corpos, em recortes de espaços e tempos singulares que definem maneiras de ser, juntos ou separados, na frente ou no meio, dentro ou fora, perto ou longe" (RANCIĖRE, 2012, p. 55).

Nestas possibilidades e impossibilidades que se apresentam no decorrer de todo o processo criativo, todas as cenas foram se aprofundando, seja na intenção de complementarem-se ou simplesmente de negarem-se mutuamente, pois ambos os casos coexistem na dramaturgia.

Tenho viva a recordação de escrita da última cena do espetáculo: a poucos meses da estreia da peça ainda não tinha a mínima ideia de como o espetáculo iria terminar. A personagem já estava bem estabelecida e o dramaturgo por vezes também tinha suas questões contempladas na peça. A penúltima cena configurava-se na apresentação de um jornal, onde a personagem Sofia recebia princesas de contos de fadas. As princesas eram bonecas que estavam na cena, presas ao espelho. A história das princesas mesclava-se aos fatos reais de travestis e transexuais assassinadas no Brasil, entre os anos de 2012 a 2014. No entanto, neste lugar da ficção, Sofia percebe que a última princesa morta era sua grande amiga Dayana.

Este foi um dos momentos de maior instabilidade da dramaturgia, pois, apesar do desejo de aprofundar o lugar da solidão retirando o último amparo desta personagem, com a qual Sofia dividia confidências e companheirismo, me soava injusto desolar esta personagem que me apoia durante os cinquenta minutos anteriores do espetáculo. Em sala de ensaio, tornou-se absolutamente claro para mim que Sofia exigia outro final.
Criei então uma cena que mantinha praticamente a mesma estrutura e a morte de sua colega de quarto. No entanto, esta personagem toma tanta força no decorrer do processo que a própria cena me pressiona a expôr minhas escolhas enquanto dramaturgo. Pensei num primeiro momento que seria uma loucura encerrar o espetáculo desta forma; no entanto, as coisas foram se encaixando e um elemento de cena, que era o espelho, me ajudou a compôr melhor este jogo, onde Sofia inicia questionando o seu final olhando para o espelho:

Escuta aqui, eu não aguento mais este fardo tá me ouvindo? Tá engraçado o final do seu espetáculo? Tá tenso, tá chocante? Mas você não vai tirar minha amiga de mim não, não vou aguentar. Não tenho escolha, como assim não tenho escolha? Você é um dramaturgo ou um gigolô? Me traz minha amiga moleque senão eu vou aí e passo a gilete em você. Você pensa que sabe de tudo sobre travestis, mas você não sabe de nada, você é apenas mais um com um olhar distante que tá cagando pra gente. Tá emocionante pra você, tá canalha? Tá bom pra quem vem te assistir mas pra mim não. Você não vai terminar a sua pecinha, comigo aqui inerte e fudida chorando não, ah mas não vai mesmo. Tá me ouvindo? (LOPES, 2014, p. 13)

Sofia então aceita seu fardo, seu peso, sua culpa histórica anterior a ela. Assim como Antígona carrega em seu sangue a maldição de Édipo, Sofia carrega o carma de um país preconceituoso, homofóbico e moralista. A desilusão e o abandono, que são recorrentes na vida das travestis no Brasil, enterram a personagem a cada noite de espetáculo, como um manifesto do próprio corpo que mostra o quanto a sociedade heteronormativa precisa ser transformada e revista perante as continuidades das leis.

Assim como no início do espetáculo, onde Sofia já se encontra em cena terminando sua maquiagem, a personagem permanece também após o fim, entregando-se ao final da vida, ao simples fechar de portas ou apagar 
das luzes de um teatro. Sofia, o ator e o dramaturgo ficam ali, permitindo que a plateia reveja um pouco mais este corpo enterrado, esta metáfora do sufocamento.

A edição da Revista Sala Preta, que tem como temática "Teatros do Real", traz em alguns artigos debates pertinentes às questões e discussões que aqui desenvolvo. No artigo Entre mostrar e vivenciar: cenas do teatro do Real, de André Carreira e Ana Maria Bulhões (2013), os teatros do real estão ligados a experiências cênicas e textuais, onde a relação com o real ficcional, no sentido político, social, coletivo ou individual, se dá. Este termo engloba uma variedade de modos de criação que partem de fontes documentais, experiências, transcrições, gravações, dentre outros, que têm como função produzir o "efeito de real", que busca a legitimidade e a veracidade dos fatos e informações. Este teatro deve então evidenciar a relação da arte com o real verdadeiro, ou, pelo contrário, que seja verdadeiro o que se tome como arte (CARREIRA; BULHÕES, 2013).

Pensar no teatro autobiográfico é, em certa medida, pensar no teatro como um lugar concreto de pactos entre a plateia e o espectador. Estes pactos se estabelecem numa linha muito tênue entre um tipo de teatro que parte de uma relação direta com fatos vividos pelo diretor, dramaturgo ou ator, mas que tem sua licença criativa para ser reescrita enquanto palavra, imagem, performance e memória. No lugar de recepção do real revisitado para a cena, o espectador pode questionar a possibilidade do próprio cotidiano, da sua vida "real" como espaço para possíveis novas realidades, novas interpretações, novos significantes. Neste caso, tanto a cena quanto o cotidiano da vida se retroalimentam.

No espetáculo Sofia -35 , a ficção ocorre a partir de um fato real, de uma memória que é editada com o tempo e com a minha forma de ver o mundo. No entanto tal fato realmente aconteceu. Todavia, o que foi construído para a cena, parte do lugar deste fato que é sujeito a comprovação, mas se transforma em linguagem artística, onde as potências do discurso e dos sentidos vão se maturando de acordo com meu percurso enquanto artista e homossexual. Quando abordo gênero em um espetáculo autobiográfico, desenvolvo um processo artístico que surge do lugar do real sujeito a comprovação, mas que se expande e possibilita aos conceitos de gênero e teatro como espaços de criação de outras ficções.

A partir da possibilidade de criação artística, o real é ressignificado em cena, onde podemos perceber que, tanto a cena quanto o nosso próprio cotidiano, são repletos de realidades editadas. Para Carreira e Bulhões:

A postura alerta e participativa do espectador tem como consequência, um pacto de ambiguidade que se estabelece com aquilo que é visto, testemunhado, já que aquela cena não pode ser transformada pela ação das testemunhas, ainda que elas estejam creditando a ela uma verdade. Pois ainda que credivel e 'real', a cena é teatral. Essa é sua condição, sempre contraditória e ambígua. Trata-se de uma cena testemunhada no teatro, e por mais realidade que dê a observar, essa realidade está, desde o início, comprometida pelas circunstâncias de sua irrupção: ela se dá num espaço de convenções pré-estabelecidas. 0 simples fato de estar ocorrendo ali, naquele lugar denominado 'espaço teatral', compromete e determina a natureza daquele real. (CARREIRA; BULHÕES, 2013, p. 34)

Neste sentido, a cena autobiográfica testemunhada no teatro, que se dá no espaço de convenções preestabelecidas, tem a possibilidade de revisitar recortes específicos da memória do artista, afirmando a reapropriação consciente desta narrativa como possibilidade potente no teatro contemporâneo. A imagem, fato, ou história, consegue reformular a cena, legitimando-se como uma nova experiência, sujeita a transformações estéticas, políticas e 
contextuais dos artistas envolvidos na função de recriar outras possibilidades para a cena.

Para Carreira e Bulhões, a identificação com o real é circunstancial e relativa. Reconhecer e constatar a cena como lugar do real ocorre no constante processo de aceitação e de descobrimento, dentro de um jogo no qual atores e espectadores são participantes ativos. "O reconhecimento da representação por parte do espectador é o elemento chave que permite exatamente a identificação do real" (CARREIRA; BULHÕES, 2013, p. 37). Percebemos então que a recepção da experiência teatral se articula de uma outra forma que não é a do teatro realista, que buscava a ilusão, não exigindo do espectador uma percepção mais política de uma arte que fricciona, desarticula e recria novas possibilidades para o sentido de realidade:

Pode-se pensar as propostas do teatro do real como práticas que reforçam os procedimentos da teatralidade realizando um retorno ao real, com vistas a criar novas tensões entre a arte e a vida... O real como moeda corrente de um teatro que pretende construir um espaço de pertencimento, como alternativa ao teatro do simples entretenimento. (CARREIRA; BULHÕES, 2013, p. 40)

No espetáculo Sofia-35, uma personagem que seria tão ficcional e distante de mim, acaba falando por mim e mais que isto, me transformando em vários momentos. Considerando a relação entre ator, dramaturgo e personagem, posso afirmar com clareza que este espetáculo enquanto experiência e que estes signos são possiveis somente pelo contato com o real que se estabelece na cena como convenção teatral.

De acordo com Fernando Kinasi, em seu artigo $O$ Gosto pelo real no teatro contemporâneo (2013), o teatro do real delimita-se não pela negação do teatro dramático, mas, pelo contrário, pelo engajamento nas questões políticas e discussões de seu tempo. Trata-se aqui de resoluções cênicas que nos ajudam a compreender e ressignificar as crises sociais de forma artística. Para o autor:

O trânsito entre ficção e realidade, a irrupção do real em cena e o questionamento radical do cosmos fictício dramático, fazem parte de novas práticas teatrais que muito pouco têm a ver com o modelo aristotélico. 0 que não significa que cedam ao canto de sereia das práticas performativas up to date. Portanto, ainda e sempre, cabe identificar o que há de mistificação na realidade social e nas práticas teatrais, incluindo aí a crítica da representação ficcional e o gosto pelo real. Não se trata, meramente, de constatar a existência de uma situação (ou crise) capaz de desmontar a representação teatral convencional, mas também de uma crise da representação teatral (que tem aspectos criativos e críticos) que pode, cenicamente (e não cinicamente), ajudar a entender e responder à crise social. (KINASI, 2013, p. 153)

Esta crítica a um modelo aristotélico que pouco problematiza a realidade na qual os artistas estão inseridos, nos ajuda a compreender que o teatro do real situa-se num lugar de transformação política da própria estética teatral hegemônica, cedendo espaço a uma arte que se aproxima ativamente do contexto do indivíduo, das crises sociais contemporâneas e de uma estética teatral potente oriunda destes tensionamentos. Estética esta que legitima a fala dos esquecidos e marginalizados historicamente: homossexuais, negros, mulheres, pobres. Não por meio de um tipo de re-educação ou mesmo por ações didáticas, mas por falar diretamente, questionar e se mostrar insatisfeita com o próprio cotidiano, fazendo com que o pacto do real seja também um pacto de reaproximação entre o teatro e seus espectadores.

Os dois artigos nos auxiliam na compreensão e percepção da arte que não se quer panfletária, mas reflete e reconfigura o seu tempo e espaço de forma sensivel. Onde o reencontro com a escuta, o relato e a história oral se potencializam. É mister salientar que, neste processo de construção e nas apresentações do espetá- 
culo, o estado de presença do ator enquanto performer é potencializado, ao passo que sua própria história de vida ganha luz, marcação, interpretação, sonoplastia e corporeidade, onde as escolhas textuais e de encenação narram não uma história que the é estranha, mas que é recontada a partir da sua produção artística. Artaud (2006) fala na necessidade da morte do teatro. Ouso dizer que a experiência com o teatro do real pode possibilitar esta morte, tendo em vista a potência que o artista tem de recriar seus mitos e de construir uma ficção outra, que não busca iludir a plateia mas, pelo contrário, busca reconectar o fio que se estabelece entre a cena e o cotidiano.

\section{Referências}

ARAÚJO, Antonio. A gênese da vertigem: o processo de criação de o paraíso perdido. São Paulo: Perspectiva; Fapesp, 2011.

ARFUCH, Leonor. 0 espaço biográfico: dilemas da subjetividade contemporânea. Tradução de Paloma Vidal. Rio de Janeiro: EDUERJ, 2010.

ARTAUD, Antonin. 0 teatro e seu duplo. Tradução Teixeira Coelho. 3a edição São Paulo. Martins Fontes, 2006.

BUTLER, Judith. Problemas de gênero: feminismo e subversão da identidade. Rio de Janeiro: Civilização Brasileira, 2015.

CAPUCHO, Ana Maria Carvalho; VIOLA, Ana Maria de. Direitos humanos: questões atuais sobre a violência contra LGBTTT (Lésbicas, gays, bissexuais, travestis, transexuais e transgêneros). São Paulo: Ed. Unisal, 2014.

CARREIRA, André; BULHÕES, Ana. Entre mostrar e vivenciar: cenas do teatro do real. Sala Preta - PPGAC, p. 33-44, 2013.
COHEN, Renato. Work in progress na cena contemporânea. São Paulo: Perspectiva, 2013.

DELEUZE, Gilles; GUATTARI, Félix. Mil Platôs (Capitalismo e Esquizofrenia). v. 1. São Paulo: Editora 34, 1995.

KINASI, Fernando. 0 gosto pelo real no teatro contemporâneo. Sala Preta - PPGAC, p. 144-154, 2013.

KULICK, Don. Travesti: prostituição, sexo, gênero e cultura no Brasil. Rio de Janeiro: Editora Fiocruz, 2008.

LIMA, Wlad. Dramaturgia pessoal do ator. Belém: Grupo Cuíra, 2005.

LOPES, Cleilson Queiroz. Sofia -35. Dramaturgia. 2014. Manuscrito inédito.

NEWTON, Esther. Mother camp: female impersonators in America. Chicago; London: The University of Chicago Press, 1972.

RANCIÈRE, Jacques. 0 espectador emancipado. Tradução de Ivone C. Benedetti. São Paulo: Editora Martins Fontes, 2012.

ROCHA, Fábio. GGB divulga número de assassinatos de Gays no ano de 2012. Disponível em: <http:/ / www.doistercos.com.br/ggb-divulga-numero-de -assassinatos-de-gay-no-ano-de-2012/>. Acesso em: 26 abr. 2016.

SANTOS, Márcia Cristina Brasil. Quando a escola é um inferno: refletindo sobre acesso e permanência na escola numa perspectiva da diversidade de gênero. In: SEMINÁRIO INTERNACIONAL ENLAÇANDO SEXUALIDADES, 3., 2013, Salvador. Anais... Salvador: Grupo Enlace, 2013. p. 1-11.

SOERENSEN, Claudiana. A carnavalização e o riso segundo Mikhail Bakhtin. Revista Travessias, XI edição, p. 318-331, 2011.

Recebido em: 21/01/2019

Aprovado em: 02/06/2019

Cleilson Queiroz Lopes é Mestre em Artes Cênicas pela Universidade Federal do Estado do Rio de Janeiro (UNIRIO). Licenciado em Artes Cênicas pela Universidade Federal do Estado do Rio de Janeiro. Ator e dramaturgo. e-mail: cleilson-lopes@hotmail.com

Endereço: Rua Francisco Alves Macedo, 42. Cohab II. Iguatu, Ceará. Telefone: (21) 965625877 